\title{
Pemilihan Jalur Karir bagi Mahasiswa Akuntansi di Politeknik Pos Indonesia
}

\author{
Muhammad Rizal Satria \\ Politeknik Pos Indonesia, Jurusan Akuntansi \\ rizalstr@gmail.com
}

\begin{abstract}
ABSTRAK - Profesi akuntansi memiliki tantangan yang semakin besar dengan diadakannya Masyarakat Ekonomi ASEAN (MEA) yang berlangsung di tahun 2015. Masyarakat Ekonomi ASEAN tidak hanya membuka arus perdagangan barang atau jasa, tetapi juga pasar tenaga kerja profesional, seperti dokter, pengacara, akuntan, dan lainnya. Pada intinya, MEA akan lebih membuka peluang tenaga kerja asing untuk mengisi berbagai jabatan serta profesi di Indonesia yang tertutup atau minim tenaga asingnya. Sejumlah syarat yang ditentukan antara lain kewajiban berbahasa Indonesia dan sertifikasi lembaga profesi terkait di dalam negeri. Persaingan yang sangat ketat perlu disiapkan oleh para mahasiswa akuntansi di Indonesia untuk bersaing dengan lulusan dari luar. Maka dari itu mahasiswa akuntansi perlu menyiapkan strategi untuk memilih jalur karir yang akan dipilih sebelum menjadi sarjana akuntansi. Pemilihan jalur karir bagi mahasiswa adalah tahap pertama dalam menentukan karir. Mahasiswa akuntansi diberikan banyak pemilihan dari beberapa profesi akuntansi atau diluar akuntansi. Penelitian tentang pemilihan jalur karir mahasiswa akuntansi telah banyak diteliti, akan tetapi penelitian seperti ini belum pernah dilakukan pada Jurusan Akuntansi di Politeknik Pos Indonesia. Penelitian ini bertujuan untuk meneliti pemilihan jalur karir mahasiswa Akuntansi di Politeknik Pos pada Tahun 2016. Penelitian ini menggunakan metode kuantitatif rancangan deskriptif, diteliti pada tahun 2016 di bulan Oktober menggunakan kuesioner dengan teknik whole sampling menggunakan sampel 56 mahasiswa. Dari hasil yang didapatkan menunjukkan mayoritas mahasiswa pada jurusan akuntansi di Politeknik Pos Indonesia tahun 2016 adalah wanita dan pemilihan jalur profesi yang paling banyak diharapkan oleh para mahasiswa adalah akuntan perusahaan. Dan mayoritas mahasiswa memilih Indonesia untuk bekerja.
\end{abstract}

Kata Kunci: Pemilihan Jalur Karir, profesi akuntansi

ABSTRACT - The accounting profession has an even more significant challenge with the holding of the ASEAN Economic Community (AEC), which took place in 2015. The ASEAN Economic Community not only opens the flow of goods or services trade, but also the professional labor market, such as doctors, lawyers, accountants, and others. In essence, MEA will open more opportunities for foreign workers to fill various positions and professions in Indonesia that are closed or lack of foreign workers. Some conditions determined include Indonesian language obligations and certification of relevant professional institutions in the country. Very tight competition needs to be prepared by accounting students in Indonesia to compete with graduates from outside. Therefore, accounting students need to make a strategy to choose the career path to be selected before becoming a graduate in accounting. The choice of 
career paths for students is the first stage in determining a career. Accounting students are given many elections from several accounting professions or outside accounting. Research on the choice of career paths for accounting students has been widely studied. Still, research like this has never been done at the Department of Accounting at Polytechnic Pos Indonesia. This study aims to examine the selection of career paths of Accounting students at the Polytechnic Post in 2016. This study uses a quantitative descriptive design method, tested in 2016 in October using a questionnaire with a whole sampling technique using a sample of 56 students. The results showed that the majority of students majoring in accounting at Polytechnic Pos Indonesia in 2016 were women, and the selection of the most expected professional paths by students was a company accountant. And the majority of students choose Indonesia to work.

Keywords: Career Path Options, the accounting profession

\section{PENDAHULUAN}

Profesi akuntansi memiliki tantangan yang semakin besar dengan diadakannya Masyarakat Ekonomi ASEAN (MEA) yang berlangsung pada 2015. Persaingan yang sangat ketat perlu disiapkan oleh para mahasiswa akuntansi di Indonesia untuk bersaing dengan lulusan dari luar. Masyarakat Ekonomi ASEAN tidak hanya membuka arus perdagangan barang atau jasa, tetapi juga pasar tenaga kerja profesional, seperti dokter, pengacara, akuntan, dan lainnya. MEA mensyaratkan adanya penghapusan aturan-aturan yang sebelumnya menghalangi perekrutan tenaga kerja asing. Pembatasan, terutama dalam sektor tenaga kerja profesional, didorong untuk dihapuskan.

Sehingga pada intinya, MEA akan lebih membuka peluang tenaga kerja asing untuk mengisi berbagai jabatan serta profesi di Indonesia yang tertutup atau minim tenaga asingnya. Sejumlah syarat yang ditentukan antara lain kewajiban berbahasa Indonesia dan sertifikasi lembaga profesi terkait di dalam negeri. Maka dari itu mahasiswa akuntansi perlu menyiapkan strategi untuk memilih jalur karir yang akan dipilih sebelum menjadi sarjana akuntansi.
Pemilihan jalur karir bagi mahasiswa adalah tahap pertama dalam menentukan karir. Mahasiswa akuntansi diberikan banyak pemilihan dari beberapa profesi akuntansi atau diluar akuntansi. Mahasiswa akuntansi sebelum diberikan gelar sarjana akuntansi perlu untuk menyiapkan strategi untuk menentukan karir yang baik. Saat ini tidak sedikit karir yang dipandang negative oleh masyarakat karena sebab tertentu (Wicaksono, 2014). Mahasiswa sangat memerlukan masukan dari para pendidik dalam merencanakan karir mereka agar studi yang mereka lakukan selama perkuliahan dapat dimanfaatkan secara baik.

$\begin{array}{cll}\text { Sarjana } & \text { akuntansi } & \text { setelah } \\ \text { menyelesaikan } & \text { Pendidikan } & \text { sarjana }\end{array}$ memiliki banyak pemilihan karir, diantaranya karyawan perusahaan, karyawan di pemerintahan maupun berwiraswasta, bahkan banyak yang memilih untuk melanjutkan Pendidikan S2. Mereka akan memiliki banyak pemilihan jalur profesi akuntansi maupun non akuntansi (Anna dan Rahayu, 2011).

Terdapat beberapa pekerjaan yang dapat dipilih oleh para lulusan akuntansi, yakni akuntan publik, akuntan pendidik, akuntan pemerintah, dan akuntan manajemen. Pada umumnya mahasiswa 
akuntansi ingin menjadi orang yang profesional dan kompeten khususnya dalam bidang akuntansi. Meskipun banyak mahasiswa dan lulusan akuntansi memilih karir yang tidak sejalan dengan bidangnya (Anna dan Rahayu, 2011). Profesi yang tidak sejalan dengan bidang akuntansi pada saat ini memang sedang marak. Profesi akuntan dinilai sangat berisiko karena perkembangan jaman dan tidak stabilnya keadaan ekonomi di Indonesia.

Semakin banyak pilihan karir yang dihadapi oleh para lulusan sarjana akuntansi membuat mereka semakin sulit dalam memilih karir tersebut. hal itu membuat pertanyaan seputar pemilihan profesi kepada lulusan sarjana akuntansi tersebut. Berikut adalah pemilihan jalur karir dari sektor pekerjaan pada lulusan D4 Akuntansi di Politeknik Pos Indonesia tahun 2015:

Tabel 1 Pemilihan Sektor Pekerjaan Lulusan Prodi D4 Akuntansi

\begin{tabular}{|c|c|}
\hline $\begin{array}{c}\text { Pemilihan Sektor } \\
\text { Pekerjaan }\end{array}$ & Persentase \\
\hline Akuntansi & $34,46 \%$ \\
\hline Non-Akuntansi & $65,54 \%$ \\
\hline TOTAL & $\mathbf{1 0 0 \%}$ \\
\hline
\end{tabular}

(Sumber: Data Lulusan Prodi D4 Akuntansi Tahun 2015)

Berdasarkan fakta tersebut, pemilihan karir mahasiswa akuntansi dinilai sangat penting untuk diteliti. Banyak penelitian terkait pemilihan karir mahasiswa akuntansi telah dilakukan. Namun, penelitian semacam ini belum pernah dilakukan di Program Studi D4 Akuntansi Keuangan pada Politeknik Pos Indonesia.

Penelitian tentang pemilihan jalur karir pada mahasiswa Akuntansi bertujuan untuk: (1) Memberikan Informasi mengenai minat pemilihan karir mahasiswa Program Studi D4 Akuntansi Keuangan, (2) Memberikan informasi bagi instansi/Lembaga terkait kebijakan- kebijakan dalam rangka penyusunan kurikulum, (3) Sebagai bahan acuan atau referensi bagi penelitian serupa.

\section{TINJAUAN PUSTAKA}

\section{Pemilihan Jalur Karir}

Pada umumnya, pemilihan jalur karir sarjana akuntansi ada 4, yaitu: akuntan publik, akuntan pendidik, akuntan pemerintah dan akuntan perusahaan (Anna dan Rahayu, 2011). Untuk menjalankan usahanya, perusahaan membutuhkan modal yang berasal dari pihak internal (pemilik) dan pihak eksternal (investor dan pinjaman dari kreditur).

Praktik akuntansi di Indonesia dimulai sejak zaman VOC (1642). Akuntan Belanda itu kemudian mendominasi akuntansi di perusahaan perusahaan yang juga di monopoli penjajah hingga abad 19. Pada masa pendudukan Jepang, pendidikan akuntansi hanya di selenggarakan oleh Departemen Keuangan berupa kursus ajun akuntan di Jakarta. Pesertanya saat itu 30 orang termasuk Prof. Soemardjo dan Prof. Hadi broto. Bersama empat akuntan lulusan pertama Fakultas Ekonomi Universitas Indonesia dan enam lulusan Belanda. Prof. Soemardjo merintis pendirian Ikatan Akuntansi Indonesia tanggal 23 Desember 1957.

Pada tahun yang sama pemerintah melakukan nasionalisasi perusahaanperusahaan milik Belanda. Hal ini menyebabkan akuntan-akuntan Belanda kembali ke negaranya dan sejak itu para akuntan Indonesia semakin berkembang. Perkembangan itu semakin pesat setelah presiden meresmikan kegiatan pasar modal 10 Agustus 1977 yang membuat peranan akuntansi dan laporan keuangan menjadi penting. Januari 1997 Menteri Keuangan mengeluarkan surat keputusan Nomor 43/1997 Tentang Jasa Akuntan menggantikan Keputusan 
Menteri Keuangan 763/1986. Selain mewajibkan akuntan publik memiliki sertifikat akuntan publik, juga akuntan publik asing diperbolehkan praktek di Indonesia sepanjang memenuhi persyaratan.

\section{Pendidikan Akuntansi}

Mahasiswa yang menempuh program pendidikan akuntansi di Perguruan Tinggi Negeri (PTN) maupun Perguruan Tinggi Swasta (PTS) menggunakan kurikulum minimal yang sama, yaitu kurikulum yang dirancang untuk menghasilkan akuntan. Bagi yang menginginkan register akuntan, mereka akan menempuh Ujian Nasional Akuntansi (UNA), sedangkan yang tidak menginginkannya mereka dapat langsung memasuki dunia kerja setelah lulus program pendidikan S1.

Akuntansi sebagai sarjana plus, dalam Surat Keputusan Menteri Pendidikan dan Kebudayaan No.036/V/1993 tentang pendidikan profesi dan sebutannya dan No.0313/V/1994 tentang kurikulum minimal yang berlaku secara nasional, mengakui bahwa akuntan adalah sebutan yang diberikan bagi lulusan pendidikan profesi akuntansi.

\section{Karir Profesi Akuntan}

Pada era globalisasi saat sekarang ini, dunia usaha dan masyarakat menjadi suatu hal yang semakin kompleks sehingga menuntut adanya perkembangan berbagai disiplin ilmu termasuk akuntansi. Akuntansi memegang suatu peranan yang sangat penting ekonomi dan sosial, karena setiap pengambilan suatu keputusan yang bersifat keuangan harus berdasarkan informasi akuntansi. Keadaan ini menjadikan akuntan sebagai suatu profesi yang sangat di butuhkan keberadaannya dalam lingkungan organisasi bisnis. Keahlian - keahlian khusus seperti pengolahan data bisnis menjadi informasi berbasis komputer, pemeriksaan keuangan maupun non keuangan.

Akuntan sekarang jumlahnya masih relatif kecil di bandingkan jumlah penduduk Indonesia saat sekarang ini. Sangat memungkinkan profesi akuntan berkembang dimasa yang akan datang, baik secara kuantitas maupun kualitas. Seiring dengan pertumbuhan ekonomi Indonesia yang di harapkan semakin baik dalam memasuki milenium ketiga, maka profesi akuntan sangat dibutuhkan dalam membantu mewujudkannya. Kondisi ini membawa pada suatu konsekuensi bahwa masih terbuka lebar bagi setiap orang untuk memasuki profesi akuntan dan profesi akuntan sebagai salah satu pilihan karier yang menjanjikan.

\section{Akuntan Publik}

Akuntan Publik melakukan tugasnya yaitu adalah memeriksa laporan keuangan dan konsultasi dibidang keuangan (Arens, 2015). Seorang akuntan yang bekerja di Kantor Akuntan Publik (KAP) akan selalu berurusan dengan klien, yaitu perusahaan yang membutuhkan jasa pada kantor akuntan publik. Hal tersebut menunjukkan bahwa jenis pekerjaan profesi akuntan publik adalah pekerjaan yang tergantung pada jasa yang diminta oleh kliennya. Jika seseorang memasuki karir sebagai akuntan publik, ia harus memiliki Pendidikan formal dan terlebih dahulu mencari pengalaman profesi di bawah pengawasan akuntan senior yang lebih berpengalaman (Naukoko,2017). Kualifikasi untuk seorang akuntan publik diantaranya: Lulus Sarjana Ekonomi S1 Jurusan Akuntansi, Lulusan Pendidikan profesi Akuntansi, Lulus ujian sertifikasi Akuntan Publik, mempunyai izin Akuntan Publik. Jika tidak memenuhi syarat dan kualifikasi diatas, maka orang tersebut 
bisa menjadi akuntan di bidang yang lain.

Akuntan yang memiliki gelar CPA belum bisa disebut sebagai seorang Akuntan Publik sehingga dia belum bisa memberikan jasa kepada pihak lain, tetapi mereka bisa menjadi Akuntan Publik. Untuk bisa mengajukan izin menjadi seorang Akuntan Publik, maka seorang akuntan bergelar CPA harus memenuhi persyaratan yang tercantum dalam Pasal 5 Peraturan Menteri Keuangan No:17/PMK.01/2008 sebagai berikut:

1) Memiliki nomor Register Negara untuk Akuntan;

2) Memiliki Sertifikat Tanda Lulus Ujian Sertifikasi Akuntan Publik (USAP/Indonesia CPA Exam) yang di selenggarakan oleh IAPI;

3) Dalam hal tanggal kelulusan USAP/Indonesia CPA sebagaimana dimaksud pada huruf $b$ telah mengikuti Pendidikan Profesional Berkelanjutan (PPL) paling sedikit 60 (enam puluh) Satuan Kredit PPL (SKP) dalam 2 (dua) tahun terakhir:

4) Berpengalaman praktik di bidang audit umum atas laporan keuangan paling sedikit 1000 (seribu) jam dalam 5 (lima) tahun terakhir dan paling sedikit 500 (lima ratus) jam diantaranya memimpin dan/atau menyupervisi perikatan audit umum yang disahkan oleh Pemimpin/Pemimpin Rekan KAP;

5) Berdomisili di Wilayah Republik Indonesia yang dibuktikan dengan Kartu Tanda Penduduk (KTP) atau bukti lainnya sesuai dengan peraturan perundangundangan yang berlaku;
6) Memiliki Nomor Pokok Wajib Pajak (NPWP);

7) Tidak pernah dikenakan sanksi pencabutan izin Akuntan Publik; dan

8) Membuat Surat Permohonan, melengkapi formulir Permohonan Izin Akuntan Publik, membuat surat pernyataan tidak merangkap jabatan dan membuat surat pernyataan bermeterai cukup yang menyatakan bahwa data persyaratan yang disampaikan adalah benar.

\section{Akuntan Pendidik}

Akuntan pendidik adalah dosen atau akuntan yang mengajar pada perguruan tinggi, selain memiliki tugas dalam pendidikan akuntansi, seperti mengajar, menyusun kurikulum pendidikan akuntansi dan melakukan penelitian di bidang akuntansi (Farida, 2017). Dalam melaksanakan tugasnya, para akuntan pendidik berpedoman pada Tri Dharma perguruan tinggi, yaitu pengajaran, penelitian, dan pengabdian kepada masyarakat.

Akuntan pendidik adalah akuntan yang memiliki tugas utama melakukan riset pengembangan bidang ilmu akuntansi, dan juga menjadi tenaga pendidik dengan memberikan pengajaran ilmu pengetahuan akuntansi. Menurut Badan Standar Nasional Pendidikan (2006: 88) kompetensi profesional yaitu kemampuan penguasaan materi pembelajaran secara mendalam dan luas yang terdiri dari penerapan konsep keilmuan di kehidupan selama sehari-hari dalam struktur, konsep, metode, teknologi yang menaungi pada materi ajar di kurikulum dan mempunyai hubungan konsep dengan mata kuliah terkait kompetisi secara profesional di dalam area global dengan tetap melestarikan nilai dan 
budaya nasional. Dimensi yang diambil dalam Kompetensi Akuntan Pendidik adalah kompetensi Akademik yang relevan dengan program studi, dan kompetensi menguasai materi ajar, membuat karya ilmiah, laporan penelitian yang relevan dan dibutuhkan program studi.

\section{Akuntan Pemerintah}

Akuntan pemerintah adalah para akuntan yang mengabdi pada badanbadan pemerintah. Badan-badan pemerintah tersebut seperti departemen, Badan Pengawas Keuangan dan Pembangunan (BPKP), Badan Pemeriksa Keuangan (BPK), dan Dirjen. Akuntan pemerintah menjalankan fungsinya sesuai dengan keahlian yang diperoleh dari lembaga pendidikan yaitu menangani dan mengawasi keuangan tetapi dalam lingkup pemerintah. Lembaga-lembaga pemerintah tersebut biasanya sudah diatur dengan undangundang, sehingga tugas dan kewajiban akuntan pemerintah disesuaikan dengan undang-undang yang berlaku.

Mahasiswa yang merencanakan karir sebagai akuntan pemerintah mengharapkan gaji awal yang lebih tinggi dan memiliki jaminan hari tua yang lebih baik dibandingkan dengan profesi akuntansi lainnya (Haswell and Holmes, 1988; Horowitz and Riley, 1990 dalam Setiyani, 2005). Akuntan pemerintah merupakan karir yang memiliki pekerjaan rutin sehingga kecil kemungkinan mengalami kesulitan dalam pelaksanaannya, dan mempunyai keamanan kerja yang tinggi Profesi akuntansi juga diperlukan meskipun pada lembaga yang kegiatannya tidak berorientasi laba (Yendrawati, 2007). Temuan ini yang menjadikan mahasiswa lebih tertarik merencanakan dan memilih berkarir sebagai akuntan pemerintah

\section{Akuntan Perusahaan}

Akuntan perusahaan adalah karyawan di perusahaan tempat mereka bekerja. Tugas pokoknya yaitu menentukan kebijakan dan prosedur yang diterapkan di perusahaan tersebut berdasarkan ketetapan dari manajemen puncak, menentukan penjagaan kekayaan perusahaan, menentukan efektif dan efisiensi sistem dan prosedur kegiatan perusahaan dan menentukan keandalan dari informasi laporan keuangan perusahaan.

Akuntan perusahaan yaitu profesi akuntan yang bekerja pada perusahaan dengan tugas yang dijalankan dengan berbagai fungsi akuntansi seperti fungsi yang berkaitan dengan sistem informasi akuntansi yang ada di perusahaan. Hansen dan Mowen (2009) menyebutkan sistem informasi akuntansi pada suatu organisasi terdiri dari sistem akuntansi keuangan yang menghasilkan informasi bagi pihak eksternal dan sistem akuntansi manajemen yang menghasilkan informasi bagi pihak internal. Menurut Soemarso (2004) akuntan perusahaan atau disebut juga akuntan intern (internal accountants) adalah akuntan yang bekerja dalam suatu perusahaan atau organisasi. Tugas yang dikerjakan dapat berupa (Soemarso, 2004): 1. Penyusunan sistem akuntansi; 2. Penyusunan laporan akuntansi kepada pihak - pihak diluar perusahaan; 3. Penyusunan laporan akuntansi kepada manajemen; 4. Penyusunan anggaran; 5 menangani masalah perpajakan; dan 6 melakukan pemeriksaan intern. Menurut Hansen dan Mowen (2009), akuntan perusahaan harus mendukung manajemen dalam semua tahap pengambilan keputusan bisnis.

\section{HIPOTESIS PENELITIAN}

Berdasarkan tinjauan pustaka, dapat ditinjau bahwa suatu hipotesis 
guna membatasi yang ingin dibuktikan pada penelitian ini. pemilihan karir mahasiswa Akuntansi, diantaranya: Akuntan Publik, Akuntan Perusahaan, Akuntan Pendidik, Akuntan Pemerintah, Wirausaha, dan belum memutuskan. Dari penjelasan tersebut maka dapat ditarik hipotesis sebagai berikut:

$\mathbf{H}_{1}$ : Pemilihan jalur karir yang akan dipilih oleh mahasiswa Akuntansi angkatan 2016.

\section{METODE PENELITIAN}

Penelitian yang dilakukan merupakan penelitian dengan kuantitatif observasional menggunakan rancangan deskriptif potong lintang. Penelitian ini dilakukan pada tahun 2016 bulan Oktober dengan menggunakan kuesioner.

\section{POPULASI DAN SAMPEL}

Populasi yang dipilih pada penelitian ini adalah mahasiswa Akuntansi Politeknik Pos Indonesia yang telah lulus dalam sidang skripsi tahun 2016. Menggunakan Teknik sampling Whole Sampling yaitu kriteria mahasiswa tahun 2016, Sampling yang digunakan sebanyak 56 orang.

\section{HASIL}

Jenis sampel menjadi karakteristik yang disajikan pada tabel 2. Jumlah mahasiswa perempuan adalah mayoritas dalam penelitian ini.

Tabel 2 Jenis Kelamin Lulusan

\begin{tabular}{|c|c|c|}
\hline Jenis Kelamin & Jumlah (N) & $\begin{array}{c}\text { Persentase } \\
(\mathbf{\%})\end{array}$ \\
\hline Perempuan & 45 & 84,91 \\
\hline Laki-laki & 11 & 20,75 \\
\hline TOTAL & $\mathbf{5 6}$ & $\mathbf{1 0 0}$ \\
\hline
\end{tabular}

Pertanyaan tentang pemilihan jalur karir dibagi menjadi tiga pertanyaan yaitu bidang pekerjaan, jenis profesi dan lokasi tempat bekerja. Hasil penelitian mengenai sektor pekerjaan pada tabel 3 dapat dilihat bahwa tidak terdapat perbedaan yang signifikan antara mahasiswa yang memilih bekerja di sektor swasta dengan yang memilih untuk bekerja di sektor publik atau pemerintah. Pada tabel 3 dapat dilihat bahwa sebagian kecil lulusan yang belum bisa memilih.

Tabel 3 Bidang Pekerjaan

\begin{tabular}{|l|c|c|}
\hline Bidang Pekerjaan & $\begin{array}{c}\text { Jumlah } \\
\text { (N) }\end{array}$ & $\begin{array}{c}\text { Persentase } \\
(\mathbf{\%})\end{array}$ \\
\hline $\begin{array}{l}\text { Pemerintah (PNS } \\
\text { atau BUMN) }\end{array}$ & 25 & 47,17 \\
\hline Swasta & 27 & 50,94 \\
\hline Belum Tahu & 4 & 7,55 \\
\hline \multicolumn{1}{|c|}{ TOTAL } & $\mathbf{5 6}$ & $\mathbf{1 0 0}$ \\
\hline
\end{tabular}

Tabel 4 membahas tentang pemilihan profesi dan dapat dilihat bahwa mayoritas mahasiswa memilih akuntan perusahaan sebagai karirnya jika dibandingkan dengan jenis profesi lainnya. Profesi akuntan pemerintah ternyata memiliki skor $32,08 \%$ (17 orang). Profesi akuntan pendidik ternyata diinginkan oleh $13,21 \%$ (7 orang). Profesi akuntan publik hanya dipilih oleh $5,66 \%$ (3 orang). Profesi lainnya yaitu wirausaha ternyata dipilih oleh 5,66\% (3 orang). Sisanya $5,66 \%$ belum bisa memilih.

Tabel 4 Jenis Profesi Pemilihan

\begin{tabular}{|l|c|c|}
\hline \multicolumn{1}{|c|}{$\begin{array}{c}\text { Pemilihan } \\
\text { Profesi }\end{array}$} & $\begin{array}{c}\text { Jumlah } \\
\text { (N) }\end{array}$ & $\begin{array}{c}\text { Persentase } \\
\mathbf{( \% )}\end{array}$ \\
\hline Akuntan Publik & 3 & 5,66 \\
\hline $\begin{array}{l}\text { Akuntan } \\
\text { Pendidik }\end{array}$ & 7 & 13,21 \\
\hline $\begin{array}{l}\text { Akuntan } \\
\text { Perusahaan }\end{array}$ & 23 & 43,40 \\
\hline $\begin{array}{l}\text { Akuntan } \\
\text { Pemerintah }\end{array}$ & 17 & 32,08 \\
\hline $\begin{array}{l}\text { Lainnya: } \\
\text { Wirausaha }\end{array}$ & 3 & 5,66 \\
\hline Belum Tahu & 3 & 5,66 \\
\hline \multicolumn{1}{|c|}{ TOTAL } & $\mathbf{5 6}$ & $\mathbf{1 0 0}$ \\
\hline
\end{tabular}


Hasil pada tabel 5 tentang lokasi tempat bekerja menunjukkan bahwa sebagian besar mahasiswa ingin untuk bekerja di Indonesia. Jumlah mahasiswa yang bersedia bekerja di luar hanya $26,42 \%$ dan lulusan yang belum memilih sebanyak $3,77 \%$.

Tabel 5 Lokasi Tempat Kerja

\begin{tabular}{|l|c|c|}
\hline \multicolumn{1}{|c|}{$\begin{array}{c}\text { Lokasi Tempat } \\
\text { Kerja }\end{array}$} & $\begin{array}{c}\text { Jumlah } \\
(\mathbf{N})\end{array}$ & $\begin{array}{c}\text { Persentase } \\
(\mathbf{\%})\end{array}$ \\
\hline Indonesia & 40 & 75,47 \\
\hline $\begin{array}{l}\text { Negara Lain di Asia } \\
\text { Tenggara }\end{array}$ & 6 & 11,32 \\
\hline $\begin{array}{l}\text { Negara Lain selain di } \\
\text { Asia Tenggara }\end{array}$ & 8 & 15,09 \\
\hline Belum Tahu & 2 & 3,77 \\
\hline \multicolumn{1}{|c|}{ TOTAL } & $\mathbf{5 6}$ & $\mathbf{1 0 0}$ \\
\hline
\end{tabular}

\section{PEMBAHASAN}

Beberapa hal yang sangat menarik untuk diperhatikan dan dianalisis dalam penelitian ini adalah perbandingan jenis kelamin, pemilihan jalur karir, pemilihan sektor karir dan pemilihan lokasi kerja. Hasil penelitian menunjukkan bahwa jumlah mahasiswa Akuntansi di Politeknik Pos mayoritas adalah perempuan.

Jika dilihat dari hasil tabel 3 , pemilihan sektor karir di pemerintah sebagai PNS dan swasta tidak menunjukkan perbedaan yang besar. Pemilihan untuk bekerja di sektor swasta dipilih oleh $3,77 \%$ mahasiswa lebih tinggi dibandingkan dengan sektor pemerintah. Hal tersebut kemungkinan dikarenakan di sektor swasta karyawan dapat kesempatan untuk memperoleh pendapatan yang lebih besar dibandingkan pemerintah, Sektor pemerintah juga kurang memperhatikan fasilitas yang baik, dibuktikan dengan fasilitas yang diberikan oleh perusahaan sektor swasta lebih menjanjikan dibandingkan dengan sektor publik, sebagai contoh sektor swasta mendapatkan layanan kesehatan yang lebih tinggi dibandingkan sektor publik.
Penelitian mendapatkan hasil bahwa pemilihan jalur karir yang dipilih mahasiswa, mayoritas memilih akuntan perusahaan $(43,40 \%)$. Hal ini sejalan dengan hasil penelitian tentang pemilihan karir mahasiswa akuntansi yang sudah dilakukan.

Pertanyaan tentang lokasi tempat kerja mendapatkan hasil bahwa mayoritas mahasiswa memilih Indonesia sebagai lokasi bekerja. Sedikit mahasiswa yang berminat untuk bekerja di luar Indonesia.

\section{PENUTUP}

Hasil penelitian yang didapatkan menunjukkan bahwa pemilihan jalur karir yang paling banyak diinginkan oleh mahasiswa Akuntansi di Politeknik Pos Indonesia pada tahun 2016 adalah akuntan perusahaan $(43,40 \%)$. Hal tersebut bisa saja disebabkan perusahaan memberikan lebih dibandingkan sektor lainnya.

Sedangkan tempat pekerjaan menunjukkan pemilihan yang paling banyak diinginkan mahasiswa adalah di Indonesia (75,47\%). Hal tersebut disebabkan kesulitan berbahasa asing dan rasa tidak percaya diri.

\section{SARAN} yaitu:

Penulis ingin memberikan saran

1. Untuk peneliti selanjutnya agar lebih baik lagi dari yang dilakukan penulis dan dapat melanjutkan penelitian menggunakan responden yang lebih banyak agar hasil penelitian dapat lebih akurat.

2. Penelitian yang penulis lakukan belum komprehensif karena hanya dapat melihat pemilihan karir dan lokasi pekerjaan, diharapkan penelitian selanjutnya dapat menganalisis faktor-faktor 
yang mempengaruhi pemilihan karir bagi mahasiswa akuntansi.

\section{DAFTAR PUSTAKA}

Ardianto, T. 2014. "Analisis persepsi lulusan akuntansi FEB UKSW terhadap pemilihan karir di bidang akuntansi". Skripsi Program S1 Fakultas Ekonomika dan Bisnis Universitas Kristen Satya Wacana Salatiga.

Anna, Y. D. dan Rahayu, S. 2011. "The Factors Affected Toward Profession Option as Accountant Public and Non Accountant Public Selected".

Arens, A. et al. 2015. Edisi 15. Auditing dan Jasa. Assurance Pendekatan Terintegrasi. Jilid 1. Jakarta: Salemba Empat.

Farida, M. Wiwik. 2017. "Memahami Kesadaran Peran Akuntan Pendidik Dalam Pembelajaran Akuntansi" Tesis Program Magister Sains Akuntansi Sekolah Pasca Sarjana Univesitas Brawijaya, Malang.

Hansen dan Mowen, 2012. Akuntansi Manajemen. Edisi 8. Jakarta : Salemba Empat.

Naukoko, A. Princilvanno, 2017. "Profesi Akuntan Di Era Masyarakat Ekonomi ASEAN". Journal of ASEAN Studies on Maritime Issues. Vol 3 No. 4

Yendrawati, R. 2007. "Persepsi Mahasiswa dan Mahasiswa Akuntansi Mengenai Faktorfaktor yang Mempengaruhi Pemilihan Karir sebagi Akuntan". Jurnal Ekonomi Universitas Islam Indonesia Yogyakarta, Vol. 5 No. 2 